\title{
Air Pollution and Asthma: Critical Targets for Effective Action
}

Frank J. Kelly · Ian S. Mudway · Julia C. Fussell

Received: September 18, 2020 / Accepted: October 19, 2020 / Published online: November 8, 2020

(C) The Author(s) 2020

\section{ABSTRACT}

Evidence to advocate for cleaner air for people with asthma is not in short supply. We know that air pollution is associated with the development and worsening of the condition and that mitigating interventions can improve respiratory outcomes. We have clear targets, particularly traffic emissions, especially in urban areas, and plenty of potentially effective actions. Road traffic must be reduced, and what remains should be cleaner and greener. Urban green spaces, safe cycle networks and wider pavements will promote active travel and leisure time exercise. Healthcare professionals must ensure people are aware of their air quality, its impact on asthma and the appropriate behaviour to safeguard health. What remains are realistic policies and effective measures, based on the correct scientific evidence, to be taken forth with political courage and investment so that air pollution no longer contributes to the development or worsening of respiratory ill health.

F. J. Kelly $(\varangle)$ · I. S. Mudway · J. C. Fussell NIHR Health Protection Research Unit in Environmental Exposures and Health, School of Public Health, Imperial College London, Sir Micheal Uren Building, White City Campus, 80-92 Wood Lane, London W12 0BZ, UK

e-mail: frank.kelly@imperial.ac.uk
Keywords: Air pollution; Asthma; Mitigating interventions; Traffic emissions

\section{Key Summary Points}

We know that air pollution is associated with the development and worsening of asthma and that improving air quality can result in respiratory health gains.

The challenge associated with achieving sustained reductions in air pollutants to reduce new-onset asthma and prevent worsening symptoms in those already afflicted should not be considered an intractable one.

We have clear targets and a wealth of opportunities to effectively act and make progress.

In this review, we discuss a broad array of interventions, targeted to multiple sectors of society, with the aim to bring multiple public health benefits, in addition to air quality improvements. 


\section{DIGITAL FEATURES}

This article is published with digital features, including a summary slide, to facilitate understanding of the article. To view digital features for this article go to https://doi.org/10.6084/ m9.figshare.13095725.

\section{INTRODUCTION}

Asthma is a common and chronic condition of the lung in which inflammation causes the bronchi to swell and narrow the airways, leading to episodic periods of wheezing, shortness of breath, cough and chest tightness. It affects around 235 million people worldwide [1]. Incidence and prevalence are higher in children, however morbidity and mortality are higher in adults [2]. Asthma tends to be a disease of more developed economies where there is some evidence that prevalence may have peaked [3]. In contrast, rates are increasing in low- and middle-income countries where outcomes are much worst [2, 4]. Superimposed upon day-to-day symptoms, sufferers experience life-threatening exacerbations lasting from days to weeks, which are caused by a variety of stressors, including respiratory viral infections, allergen exposure and air pollution. There is now consistent evidence that exposure to traffic-related air pollution (TRAP; particularly nitrogen dioxide $\left[\mathrm{NO}_{2}\right]$ ) is associated with an increased risk of developing asthma across the entire life course, and evidence is accumulating for a link between poor indoor air quality and new cases $[5,6]$. A recent global (incorporating 194 countries and 125 major cities) estimate of the burden of paediatric asthma incidence attributable to ambient $\mathrm{NO}_{2}$ at a spatial resolution fine enough to resolve intra-urban and near-roadway exposure gradients reported that each year 4 million new paediatric asthma cases could be attributable to $\mathrm{NO}_{2}$ pollution; $64 \%$ of these in urban centres (Table 1) [7]. The work also estimated that about $97 \%$ of children lived, and $92 \%$ of new asthma cases attributable to $\mathrm{NO}_{2}$ occurred, in areas with annual average $\mathrm{NO}_{2}$ concentrations lower than the World Health
Organisation's annual air quality guideline of $40 \mu \mathrm{g} / \mathrm{m}^{3}$.

Whilst there is no known cure for asthma, pharmacological intervention significantly improves symptoms [8, 9]. Unfortunately, however, despite international guidelines, treatment compliance rates $(>80 \%)$ required to maintain disease control is often poor, even in countries where treatment is readily accessible $[10,11]$. Reducing the onset of asthma and safely controlling symptoms through air pollution mitigation strategies, discussed herein, should therefore be regarded a significant component of the overall armamentarium against this debilitating respiratory condition.

The studies selected for inclusion in this review were collected through a search of the PubMed database and grey literature using the following keywords: 'asthma' AND 'air pollution' OR 'traffic' OR 'indoor air' OR 'particulate matter (PM)' OR ' $\mathrm{NO}_{2}$ ' OR 'oxides of nitrogen $\left(\mathrm{NO}_{x}\right)^{\prime}$ OR 'diesel' AND 'mitigating' OR 'interventions' OR 'policy' OR 'reducing' OR 'action' OR 'public awareness'. The information included in this review has been chosen to deliver a broad discussion of interventions, targeted to multiple sectors of society, to reduce the burden of air pollution on the prevalence and severity of asthma.

This article is based on previously conducted studies and does not contain any new studies with human participants or animals performed by any of the authors.

\section{IMPROVING AIR QUALITY CAN RESULT IN RESPIRATORY HEALTH GAINS}

Data from many parts of the world strongly suggest that policies designed to reduce air pollution can improve respiratory outcomes. In California, reductions in $\mathrm{PM}_{2.5}$ (PM with a diameter $<2.5 \mu \mathrm{m}$ ) and $\mathrm{NO}_{2}$ between 1993 and 2014 reduced the risk of incident asthma in children by $20 \%$ (Fig. 1) [12]. In a Swiss cohort of adults, a decline in $\mathrm{PM}_{10}$ (PM with a diameter $<10 \mu \mathrm{m}$ ) concentrations from 1990 to 2001 was associated with a $9 \%$ decrease in the annual rate of decline in forced expiratory volume in $1 \mathrm{~s}$ 
Table 1 Annual number and percentage of new asthma cases attributable to ambient nitrogen dioxide exposure for children aged $1-18$ years

\begin{tabular}{|c|c|c|c|}
\hline Regions $^{\mathrm{a}}$ & $\begin{array}{l}\text { New asthma cases due to } \\
\mathrm{NO}_{2} \text { exposure per year, } \\
\text { thousands }(95 \% \mathrm{UI})^{\mathrm{b}}\end{array}$ & $\begin{array}{l}\text { New asthma cases due to } \mathrm{NO}_{2} \\
\text { exposure per year, per } 100000 \\
\text { children }(95 \% \mathrm{UI})^{\mathrm{b}}\end{array}$ & $\begin{array}{l}\text { New asthma cases due to } \mathrm{NO}_{2} \\
\text { exposure per year, \% of total } \\
\text { incidence }(95 \% \mathrm{UI})\end{array}$ \\
\hline \multicolumn{4}{|c|}{ High-Income regions } \\
\hline Australasia & $12(5.2-15)$ & $170(77-230)$ & $8.7 \%(3.8-11)$ \\
\hline $\begin{array}{l}\text { High- } \\
\text { income } \\
\text { Asia } \\
\text { Pacific }\end{array}$ & $97(46-120)$ & $300(140-370)$ & $25 \%(12-32)$ \\
\hline $\begin{array}{l}\text { High- } \\
\text { income } \\
\text { North } \\
\text { America }\end{array}$ & $270(120-340)$ & $310(140-400)$ & $19 \%(8.5-24)$ \\
\hline $\begin{array}{l}\text { Southern } \\
\text { Latin } \\
\text { America }\end{array}$ & $56(26-72)$ & $290(130-370)$ & $18 \%(8.4-23)$ \\
\hline $\begin{array}{c}\text { Western } \\
\text { Europe }\end{array}$ & $150(70-200)$ & $190(85-240)$ & $17 \%(7.8-22)$ \\
\hline \multicolumn{4}{|c|}{ Latin America and Caribbean } \\
\hline $\begin{array}{l}\text { Andean } \\
\text { Latin } \\
\text { America }\end{array}$ & $73(33-94)$ & $340(150-440)$ & $15 \%(6.7-19)$ \\
\hline Caribbean & $39(17-51)$ & $280(120-360)$ & $10 \%(4.4-13)$ \\
\hline $\begin{array}{l}\text { Central } \\
\text { Latin } \\
\text { America }\end{array}$ & $240(110-310)$ & $260(120-330)$ & $15 \%(6.7-19)$ \\
\hline $\begin{array}{l}\text { Tropical } \\
\text { Latin } \\
\text { America }\end{array}$ & $150(66-190)$ & $230(100-290)$ & $13 \%(5.8-17)$ \\
\hline \multicolumn{4}{|c|}{ Sub-Saharan Africa } \\
\hline $\begin{array}{l}\text { Central } \\
\text { sub- } \\
\text { Saharan } \\
\text { Africa }\end{array}$ & $61(27-79)$ & $110(47-140)$ & $5.1 \%(2.3-6.7)$ \\
\hline $\begin{array}{l}\text { Eastern } \\
\text { sub- } \\
\text { Saharan } \\
\text { Africa }\end{array}$ & $150(63-190)$ & $76(33-100)$ & $4.4 \%(1.9-5.9)$ \\
\hline
\end{tabular}


Table 1 continued

\begin{tabular}{|c|c|c|c|}
\hline Regions $^{a}$ & $\begin{array}{l}\text { New asthma cases due to } \\
\mathrm{NO}_{2} \text { exposure per year, } \\
\text { thousands }(95 \% \mathrm{UI})^{\mathrm{b}}\end{array}$ & $\begin{array}{l}\text { New asthma cases due to } \mathrm{NO}_{2} \\
\text { exposure per year, per } 100000 \\
\text { children }(95 \% \mathrm{UI})^{\mathrm{b}}\end{array}$ & $\begin{array}{l}\text { New asthma cases due to } \mathrm{NO}_{2} \\
\text { exposure per year, \% of total } \\
\text { incidence }(95 \% \mathrm{UI})\end{array}$ \\
\hline $\begin{array}{l}\text { Southern } \\
\text { sub- } \\
\text { Saharan } \\
\text { Africa }\end{array}$ & $46(20-60)$ & $160(69-200)$ & $8.6 \%(3.8-11)$ \\
\hline $\begin{array}{l}\text { Western } \\
\text { sub- } \\
\text { Saharan } \\
\text { Africa }\end{array}$ & $210(92-280)$ & $110(49-150)$ & $7.6 \%(3.3-9.9)$ \\
\hline $\begin{array}{l}\text { North } \\
\text { Africa and } \\
\text { Middle } \\
\text { East }\end{array}$ & $570(260-730)$ & $270(120-350)$ & $17 \%(7.6-21)$ \\
\hline South Asia & $520(230-680)$ & $82(37-100)$ & $14 \%(6.3-18)$ \\
\hline \multicolumn{4}{|c|}{ Southeast Asia, East Asia, and Oceania } \\
\hline East Asia & $800(370-1000)$ & $260(120-340)$ & $19 \%(8.9-25)$ \\
\hline Oceania & $3.1(1.4-4.1)$ & $82(36-110)$ & $3.1 \%(1.4-4.1)$ \\
\hline $\begin{array}{l}\text { Southeast } \\
\text { Asia }\end{array}$ & $440(200-570)$ & $200(89-260)$ & $9.4 \%(4.2-12)$ \\
\hline \multicolumn{4}{|c|}{ Central Europe, Eastern Europe, and Central Asia } \\
\hline $\begin{array}{l}\text { Central } \\
\text { Asia }\end{array}$ & $46(21-60)$ & $160(70-200)$ & $16 \%(7.0-20)$ \\
\hline $\begin{array}{l}\text { Central } \\
\text { Europe }\end{array}$ & $29(13-38)$ & $130(60-170)$ & $14 \%(6.1-18)$ \\
\hline $\begin{array}{l}\text { Eastern } \\
\text { Europe }\end{array}$ & $68(31-88)$ & $180(80-230)$ & $17 \%(7.6-21)$ \\
\hline Global & $4000(180-5200)$ & $170(77-220)$ & $13 \%(5.8-16)$ \\
\hline
\end{tabular}

Reprinted from The Lancet Planetary Health, Vol 3(4), Achakulwisut P, Brauer M, Hystad P, Anenberg SC, Global, national, and urban burdens of paediatric asthma incidence attributable to ambient NO2 pollution: estimates from global datasets, e170., Copyright (2019), with permission from Elsevier

$\mathrm{NO}_{2}$, Nitrogen dioxide; UI, uncertainty interval (reflect uncertainties in the relative risk estimates of childhood asthma incidence attributable to traffic-related $\mathrm{NO}_{2}$ pollution)

a Countries are grouped into regions according to the Institute for Health Metrics and Evaluation (IHME; Seattle, WA, USA) specification

b Numbers are rounded to two significant figures 

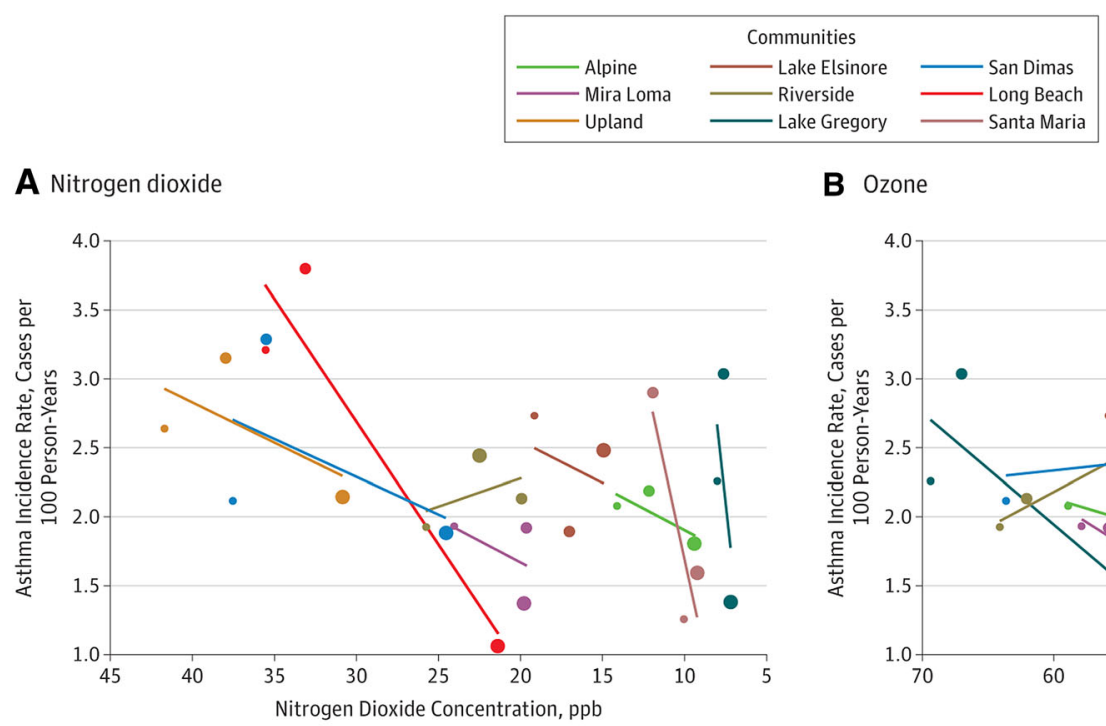

B Ozone

C Particulate matter $\leq 10 \mu \mathrm{m}$
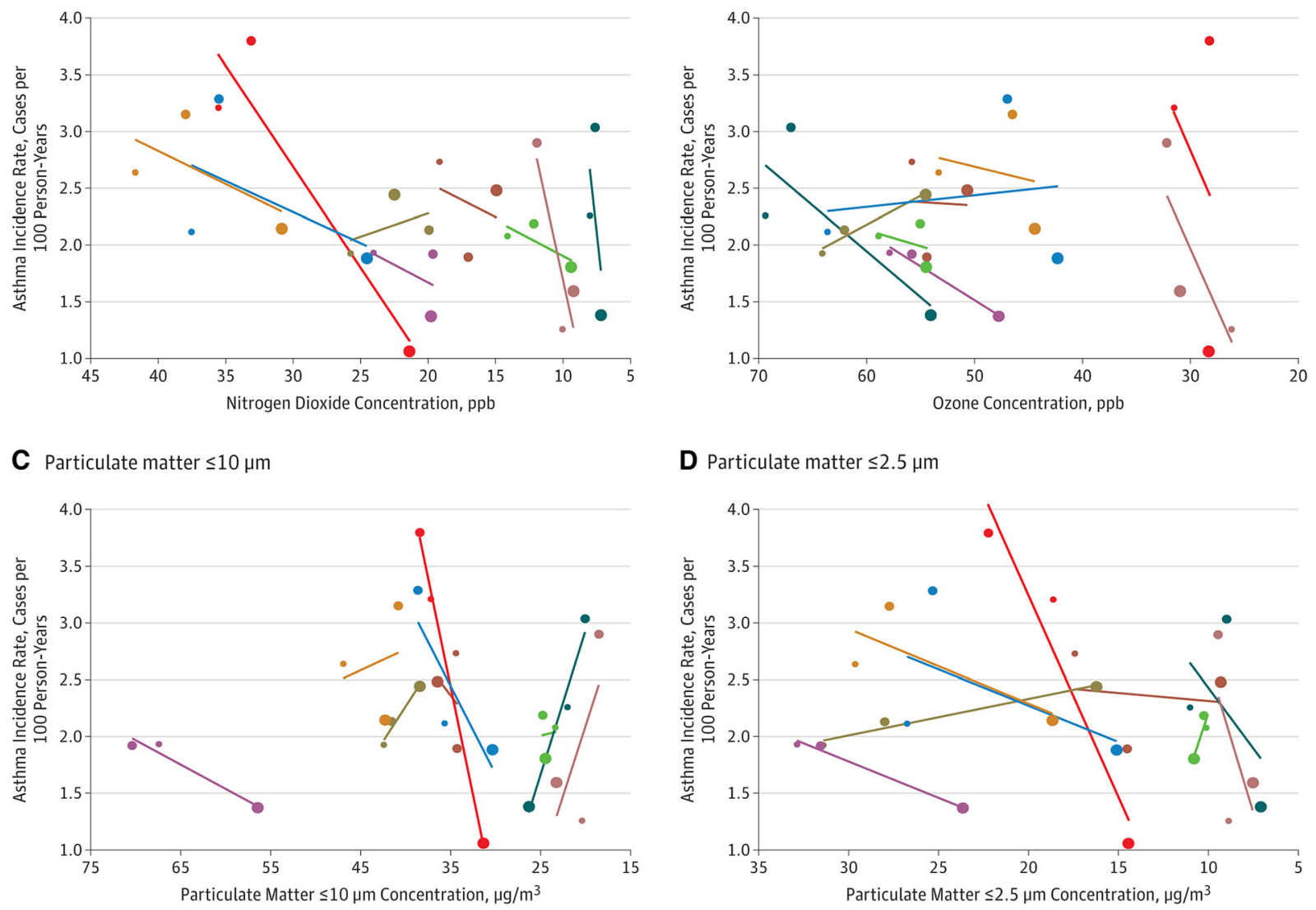

D Particulate matter $\leq 2.5 \mu \mathrm{m}$

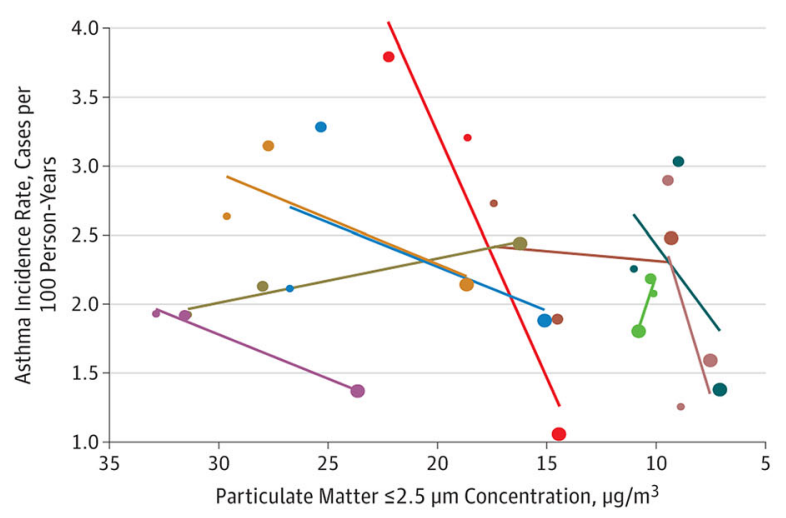

Fig. 1 Asthma incidence rates and air pollutant concentrations in nine communities during the 1993-2001, 1996-2004 and 2006-2014 cohorts of the Southern California Children's Health Study, 1993-2014 [12]. Symbol colour indicates the community, and symbol size (small, medium, large) indicates the data are from the 1993-2001 (small), 1996-2004 (medium) and 2006-2014 (large) cohorts, respectively. Simple linear

regression models based on asthma incidence and air pollution concentration were used to generate regression lines separately for each community. $p p b$ Parts per billion. Reproduced from Garcia et al. (JAMA. 2019; 321(19):1906-1915), with permission from JAMA. Copyright (C) 2019 American Medical Association. All rights reserved

$\left(\mathrm{FEV}_{1}\right)$ [13]. A follow-up study found that for every 10,000 persons in the community, a further decline in $\mathrm{PM}_{10}$ from 1991 to 2002 was associated with 137 fewer people with wheeze or shortness of breath [14]. In Japan, legislation was passed in 2001 to limit transportation-related emissions. By 2009, decreases in $\mathrm{PM}_{2.5}$ and $\mathrm{NO}_{2}$ were linked to a lower (0.6-1.1\%) prevalence of paediatric asthma [15]. Benefits have

also been observed following local air quality interventions associated with factory closures and hosting of Olympic games. Hospital admissions for childhood asthma fell by half, in association with a significant reduction in $\mathrm{PM}_{2.5}$, because of a 13-month closure of a steel mill in the Utah valley [16]. A 17-day "alternative transportation strategy" implemented by the City of Atlanta in the summer of 1996 
brought about a $23 \%$ decrease in peak morning traffic; within 4 weeks of this decrease, there was a $42 \%$ reduction in children seeking medical care and a 19\% decrease in hospitalisations for asthma [17].

In preparation for the 2008 Beijing Olympics, the Chinese government enacted factory emission and travel restrictions that resulted in pollutant concentrations decreasing by up to $62 \%$ [18]. Within 2 months, these reductions were linked to an improvement in lung function among both healthy adults and those with asthma [19] as well as 58\% fewer asthma-related physician visits [18]. Benefits of improving indoor air quality have also been documented. Installing less polluting heating appliances (heat pump, wood pellet burner, flued gas) in homes of children with asthma in New Zealand reduced symptoms, days off school, healthcare use and visits to a pharmacist [20]. Australian schools randomly allocated either to retain unflued gas heaters or have replacement flued gas/electric heaters installed reported a significant reduction in breathing difficulties, chest tightness and asthma attacks in the intervention group [21].

\section{CHALLENGES CREATE OPPORTUNITIES}

The substantial challenges associated with achieving the sustained reductions in air pollutants necessary to reduce new-onset asthma and to prevent a worsening of symptoms in those already afflicted reflect not only the insidious nature of this environmental insult, but also the wealth and complexity of issues entwined with sub-optimal air quality. Europe's car fleets have been transformed to being powered by diesel (emitting more PM and $\mathrm{NO}_{x}$ than their petrol or hybrid counterparts) [22]. The powering of light and heavy goods vehicles [23], machinery on the ground [24] and ships in the port area [25] are also dominated by diesel. Schools are invariably sited near busy roads and traffic junctions made worse by the 'school run' that is synonymous with idling engines as parents drop off or wait for their children [26]. In 2016, 400 schools within London were in areas exceeding the annual mean $\mathrm{NO}_{2} \mathrm{EU}$ limit value [27]. People on low incomes and ethnic minorities tend to be more affected than others by equivalent exposure to air pollutants [28] and are also exposed to some of the worst outdoor and indoor air quality [29, 30]. Indoor environments, where most human activities now take place within an enclosed space, are characterised by a chemically diverse and complex air quality [31]. Furthermore, unlike tobacco smoke, healthcare professionals have yet to take effective ownership of the problems that air pollution inflicts on society. On a more optimistic note, and one that this commentary attempts to take, such a challenge should not be regarded as intractable, but one in which there plenty of opportunities and ways, some of which are discussed below, to effectively act and make progress.

\section{TARGETS FOR ACTION}

\section{Road Traffic}

One of the most significant sources of air pollution in urban areas, where $55 \%$ of the world's population now resides [32], is road traffic (exhaust emissions, as well as particles from tyre, brake and road surface wear). It is, as stated earlier, also the source that has repeatedly been shown to cause/worsen asthma. The main TRAPs of concern to health in European cities are $\mathrm{PM}_{2.5}$ (particularly the fraction derived from the tailpipe) and $\mathrm{NO}_{2}$. In London in the UK, traffic is responsible for around $80 \%$ of $\mathrm{NO}_{x}$ and $37 \%$ of $\mathrm{PM}_{10}$ and $\mathrm{PM}_{2.5}$ concentrations at roadside locations [33]. This is not only due to the significant growth in vehicle numbers, but also to failures of vehicle manufacturers to ensure that they meet emissions limits in realworld driving conditions. Across 11 markets, representing approximately $80 \%$ of global diesel vehicle sales, Anenberg et al. [34] reported that over one-half of light-duty and nearly one-third of heavy-duty diesel vehicle emissions are in excess of certification limits. Cleaning up the air in heavily populated urban areas to reduce the heavy toll on people with asthma therefore requires a reduction in road traffic as well as a 
cleaner and greener element to what remains on the road.

\section{Cleaner Vehicles}

Cleaner fossil-fuelled vehicles require tougher regulations to reduce exhaust emissions, not only for new vehicles, but also afterwards in annual safety/roadworthy tests. Commonly cited disincentives aimed at removing the most polluting components of the fleet, i.e. those fuelled by diesel, include levies on fuel, surcharges for parking and the introduction of lowemission zones (LEZ). However, whilst largescale LEZs can deliver improvements in urban air quality, data suggest that, at least in densely populated European cities, more ambitious schemes are required to meet legislative limits and deliver improvements to childhood respiratory health, including asthma symptoms [35]. The introduction and rigorous evaluation of zones with greater reductions in pollutant concentrations are clearly warranted and may benefit from adjuvant clean air zones that introduce no vehicle idling areas, minimise congestion and support active and low-emission travel through the integration of public transport networks, including park-and-ride schemes.

The continued development of new technologies by motor manufacturers in producing vehicles that rely on alternative fuels (electricity, hydrogen) coupled with seamless interfaces with sustainable energy suppliers must also be actively encouraged and incentivised. Alternatively fuelled vehicles are not however the sole answer to poor air quality since zero-emission road transport does not currently exist. Particulate pollution from road traffic not only includes engine emissions, but also an increasing contribution from brake/tyre wear and road surface abrasions [36]. It is noteworthy that the potential of non-tailpipe emissions to elicit health effects is largely ignored at the regulatory level despite links with pulmonary toxicity [37]. To this end, non-tailpipe particulate pollution must be tackled by considering regulation in line with exhaust emissions and innovations in the development of 'safer' tyres, brakes and road surfaces.

Procurement of appropriate vehicles in the public and commercial sectors is crucially important and nowhere more so than for school buses. Data from the USA show that although school bus commutes usually make up only a small part of a child's day, they can contribute up to one-third of a child's 24-h overall exposure to black carbon during a school day [38]. Moreover, data support the emission reduction benefits of high-efficiency cabin air filtration system [39] and anti-idling [26], as well as health benefits associated with changing fuel from diesel to compressed natural gas [40].

It should also be stressed that cleaner road transport will not only emerge from the vehicle itself, but also from practices, such improved energy-efficient driving skills that could be introduced through tests and training programmes. For example, a smooth driving style (vs. frequent stopping and starting) ensures that motorists travel steadily at an optimum speed, thereby reducing fuel consumption and in turn air pollution through reduced exhaust emissions, as well as particles emitted from brake and tyre wear $[36,41]$.

\section{Fewer Vehicles}

The safe and efficient movement of people around towns and cities ultimately necessitates fewer vehicles. This can only be achieved through: (1) clean, efficient and expanded public transport systems coupled with car share/club schemes and (2) as much active transport in the form of walking and safe cycling as is feasibly possible. People need to be given more cost-effective and easier alternatives to move through the urban environment, be that on the school run and/or on the commute to work, without necessarily owning a car or taking one out for short journeys. A report by the European Court of Auditors reveals that commuters in Europe are still choosing their cars over public transport, enduring ever-longer journey times into some city centres owing to traffic congestion [42]. Cost, convenience and time-efficiency were all factors cited as challenges in persuading citizens to leave the comfort of their cars for other forms of transport. It is likely however that perception and beliefs also come into play, with car ownership construed to be symbols of success and social status [43]. 


\section{The Built Environment}

The built environment incorporates multiple components that can influence local air quality and in turn ill health. Some examples include neighborhood design (walkability, bikeability, connectivity), housing quality, schools, transport facilities (roads, railways, ports, airports), power plants, industrial facilities, accessibility to shops and green space. Cities created prior to the introduction of cars tend to be more densely populated and more walkable compared to newer conurbations, which tend to be less populated and more reliant on cars for transport. A vicious circle often ensues in that the mass use of cars in newer cities often goes hand in hand with inadequate public transport, poor infrastructure for active commuting, lack of green space and higher exposures to air pollution.

Strategies to clean up the air in cities of all ages should focus on the 'cleaner/fewer vehicles' formula already discussed. A cleaner element should be encouraged by not only providing, but also maintaining, adequate charge points for electric vehicles. Fewer vehicles will ensue from siting new buildings in locations near essential amenities, thereby reducing the requirement for motorised travel and thus minimising the exposure of vulnerable/disadvantaged groups to inadequate air quality. This could be achieved by locating new homes for essential workers, schools, nurseries and care homes away from roads and avoiding the creation of configurations such as deep street canyons that encourage dangerous concentrations of air pollution to build up [44]. When air pollution limits are exceeded, local authorities need to act strategically to close or divert roads to reduce the volume of traffic, especially near schools and vulnerable communities. This of course can only be achieved by adequate, accurate and accessible air pollution monitoring programmes. Planting trees and the construction of green walls and roofs to create an organic barrier to intercept PM and absorb gaseous pollutants have had mixed results by either improving air quality or in fact worsening it by restricting street ventilation. That the absolute effect of urban greening strategies will depend on factors such street configuration and canopy design means that the appropriate management of urban vegetation (siting, choice of species, maintenance regimes) is critical to maximise potential benefits [45]. With relevance to asthma, any beneficial and cost-effective to these greening strategies should avoid the use of highly allergenic plants. Failure to do so risks marginal gains in air quality being offset by a significant increased risk of exposure to known triggers of asthma exacerbations [46].

\section{Getting Active}

Compared to the growth in the volumes of road traffic in the UK over the last 60 years, active transport (walking and cycling) has been on the decline [5] despite its social, economic and health benefits [47-49]. Well-designed and maintained urban green spaces, coupled with fewer vehicles on the road to permit expanded safe cycle networks, wider pavements and other public areas (as discussed above) will create the much-needed opportunities for active travel. Additional mechanisms to promote a step change include mandatory cycle training at schools, cycle-to-work schemes and steps to support cyclists and pedestrians by, for example, providing a choice of routes to avoid highly polluted roads.

Beyond active transport to reach schools, higher education establishments and workplaces, the provision of pleasant and mixed-activity spaces will also encourage more exercise taken as a form of leisure. A marvellous exemplar is the infamous La Ciclovía in Bogotá that, every Sunday between 0700 and 1400 hours, hands 75 miles of its usually choking city streets over to over 1 million cyclists, skaters, walkers, runners and other athletes (Fig. 2) [50]. This much-loved programme began in 1974 as a citizen protest that the city was becoming too car-focused, and now attracts city-dwellers of all ages and social backgrounds who exercise alongside each other through the colourful neighbourhoods of Columbia's capital city [51]. As one of the world's most successful mass recreation events, it has become one of the 


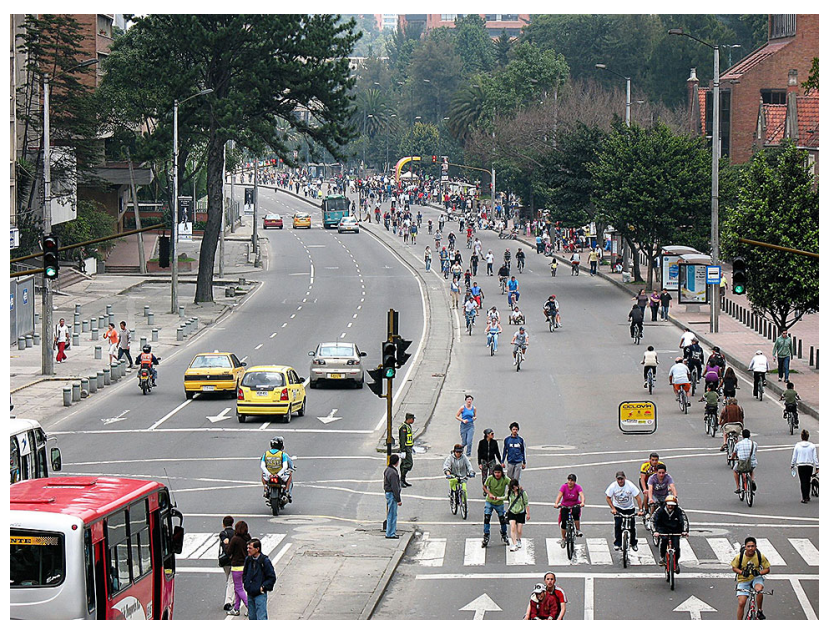

Fig. 2 Active streets during La Ciclovía in Bogotá

city's most famous exports. Ciclovías have sprung up in numerous South American countries as well as cities in Canada and the United States.

We need more Ciclovías around the world to provide a tangible vision of what a city with more cycle paths and fewer cars might look like, not just for weekly recreation, but also how cities could be designed and run differently. In addition, by truly embracing young children, they can create a generation that look at the street from a completely different perspectiveone that feels like an extension of their driveway and is therefore a safe place for recreation in a dense urban metropolis. Promoting physical activity in car-free urban spaces is a double positive for asthmatics in reducing TRAP, increasing exercise and promoting healthier lifestyles and wellbeing. Evolving research suggests that structured exercise routines may help improve some aspects of asthma control. Indeed, results from several recent systematic reviews and meta-analyses not only strongly support the safety of structured exercise routines in children and adults with asthma, but also suggest such routines favour improvements in asthma symptoms and quality of life [52].

\section{Indoor Spaces}

Up until relatively recently, air pollution was invariably deemed to be solely an outdoor issue, in the general belief that the confines of an inside space, and particularly one's home, offer protection. There are however unique factors which, when combined, have created challenges to indoor living: increased time spent indoors owing to dramatic changes in the lifestyle and working conditions of modern society [6]; the transition from natural (wooden floors and woolen carpets) to synthetic (synthetic floor coverings with added stain repellants and flame retardants) materials that have been introduced into indoor spaces [53]; the construction of energy-efficient-and with this, airtight-homes that lack inadequate ventilation and promote the buildup of air pollutants $[54,55]$. In response to these trends and evidence that ill-health, including the severity and/or prevalence of asthma, is heightened by many indoor air pollutants, including $\mathrm{NO}_{x}$ from gas cooking [56], cleaning products [57], formaldehyde [58], phthalates [59], allergens [60], mould [61] and carbon monoxide [62], a set of recommendations from experts and young people have recently been published [6]. This welcome initiative provides wide-ranging advice for Government, local authorities, building and child healthcare professions and the public about the changes that are needed ensure that air quality in homes, nurseries and schools does not pose a health risk to children. 


\section{Scientific Research}

There is clearly ample evidence to advocate for cleaner air for people with asthma, but since clear and objective scientific assessments are so crucially important to guide the development of evidence-based public health policies, there remains the need for further cross-disciplinary research into the respiratory health effects of air pollution, as well as the effectiveness of mitigation strategies. For example, the independent effects of $\mathrm{NO}_{2}$ and $\mathrm{PM}$ are still unclear and need to be deciphered, especially at a time when uptake of electric vehicles is eliminating $\mathrm{NO}_{2}$ emissions, with little of no impact on PM emissions from tyre and brake wear [63]. Another area of uncertainty is the potential of PM from biomass burning to contribute to asthma. This is especially pertinent in the light of the fashionable return of residential wood burning in Europe owing to aesthetic appeal and quest to reduce fossil fuel combustion [64]. Research themes applicable to indoor spaces that require greater scientific understanding include the benefits of indoor air filtration, placement of building air intake away from sources of air pollution and vegetative/physical barriers between roadways and homes and schools. Such areas of research will benefit from the considerable advances in mobile sensors that can be carried by individuals to monitor personal air pollutant exposure, as well by modeled-based approaches using big data. One such exemplar that is the Breathe London: Wearables study that provided 250 children and 33 teachers with wearable sensors to carry to and from school to characterise London's school children's exposure to air pollution [65]. Initiatives such as this one, which gathered 490 million measurements, create unique data sets to determine where children may be exposed to elevated concentrations and which forms of transport are more polluting, and to compare air quality within and surrounding schools. Validation studies are also reporting coherent epidemiological trends that support the use of smart phone application (app)-sourced data to examine relationships between asthma symptoms and air quality [66, 67]. These rapidly evolving technologies will enable estimates of personal air pollution exposures for large populations-currently an elusive goal, but a central one to determine health impacts, evaluate exposure sources, detect susceptible populations and identify intervention opportunities.

\section{Educate the Professionals}

When individuals, especially vulnerable patients with respiratory problems such as asthma and chronic obstructive pulmonary disease, are exposed to such a well-established and preventable cause of ill health and premature death, our public health and healthcare professionals must have the knowledge to provide sound, evidence-based advice. This requires training about air quality and health risks and being equipped with toolkits to screen and identify at risk populations, raise public awareness, influence behavioural change, help prevent and/or control associated disease and take collective action to bring about positive change. Defining patient exposure to air pollution can be difficult since sources and composition vary between communities and within households. One way to open up knowledge and awareness would be for primary healthcare workers to simply pose pertinent questions to patients, alongside those already asked about diet, exercise, smoking and alcohol, and document the answers in medical records [68]. For indoor air pollution, asking what type of fuel is used for cooking and heating, how the home is ventilated and what sort of cleaning, do-ityourself and personal care products are routinely used may provide important information to help gauge the extent of exposure and advise on lifestyle or products changes that can improve indoor air quality. An understanding of outdoor air pollution exposure requires clinicians to be equipped with reliable local air pollution data supplied by a reputable source, whilst questions to patients should focus on proximity of the household/workplace to urban or industrial environments, commuting practices, occupation and time spent near heavy traffic. Additional inquiries to provide a qualitative picture of exposure should focus on outdoor physical exertion (e.g. active transport 
during commutes, manual work, exercising) and open-ended questions about air pollution in the local community to identify any sources of risk that may otherwise go undetected. Such a screening approach will allow clinicians to be better placed to design and discuss individualtailored strategies. Recommendations to reduce exposure should always emphasize the importance of avoiding the pollutant source-the most effective intervention. They must also be practical and inexpensive and guard against negative behavioural patterns, such as healthy individuals avoiding outdoor exercise. Furthermore, recommendations must avoid advocating the use of inaccurate personal pollution-monitoring devices and any interventions designed to reduce air pollution exposure/the risk of adverse respiratory outcomes that are scientifically unproven. The public must also have access to engaging and high-quality educational materials in primary care and hospital settings. This will go some way in ensuring patients (including low-risk individuals) are better informed on this key issue.

As influential members of the community, healthcare workers have a particularly important role to play in advocating for cleaner and safer air on behalf of their patients and thereby advance the global effort to combat the adverse effects of air pollution. A hugely successful analogy is the effective anti-tobacco campaigns that facilitated the smoke-free legislation. The resulting health gains documented worldwide exceeded expectation, including a reduction in childhood and adult hospital admissions for asthma [69].

\section{Raise Public Awareness}

Outside of clinical settings, approaches to raise awareness of air quality where people, and especially susceptible individuals, congregate (e.g. bus stops, rail stations, shopping areas, etc.) are a crucial as a way of warning of the potential health risks. In an ideal world, people should also regularly check an air quality index (using traditional and social media) or a smart phone app before going to work or school or pursuing leisure activities, prompting them to take action (reduce exposure and/or increase use of inhaled reliever medication) in the event of increased pollution [70]. Alert services accessed via apps are becoming increasingly informative and engaging by providing realtime data and proactively warning registered users of impending pollution events (Fig. 3) $[71,72]$. These services also offer tailored advice on how specific groups can reduce emissions by, for example, providing low-pollution journey planners to reduce exposure. The Breathe London: Wearables study described earlier spans the scientific research/public awareness divide by introducing initiatives such the relatable presentation of collected data to participating school communities, science lessons and surveys/focus groups for children and parents to assess views and perceptions of air pollution [65].

\section{CONCLUSIONS}

To recap, we do not have a shortage of evidence to advocate for cleaner air for people with asthma. We know that air pollution is associated with the development and worsening of the condition and, importantly, since we are dealing with an avoidable health risk, mitigating interventions can result in prompt and substantial health gains. We also have a clear target, namely traffic emissions, especially in urban areas, and plenty of potential actions to safeguard the health of people of all ages. This is all good news. A crucial component to what remains is political will, guided by the science, since the recommendations discussed herein would need to be supported by a new Clean Air Act, based upon World Health Organisation health-based air quality limits, the adequacy of which are currently being revisited. However, deciding upon and executing the necessary policies is a complex challenge when it necessitates among other measures, a reduction in road traffic and a cleaner and greener element to what remains on the road-coupled to a heavy burden of expenditure. Policymakers are invariably torn between tightening controls on emissions to enhance health and succumbing to economic pressures not to reduce emissions. 


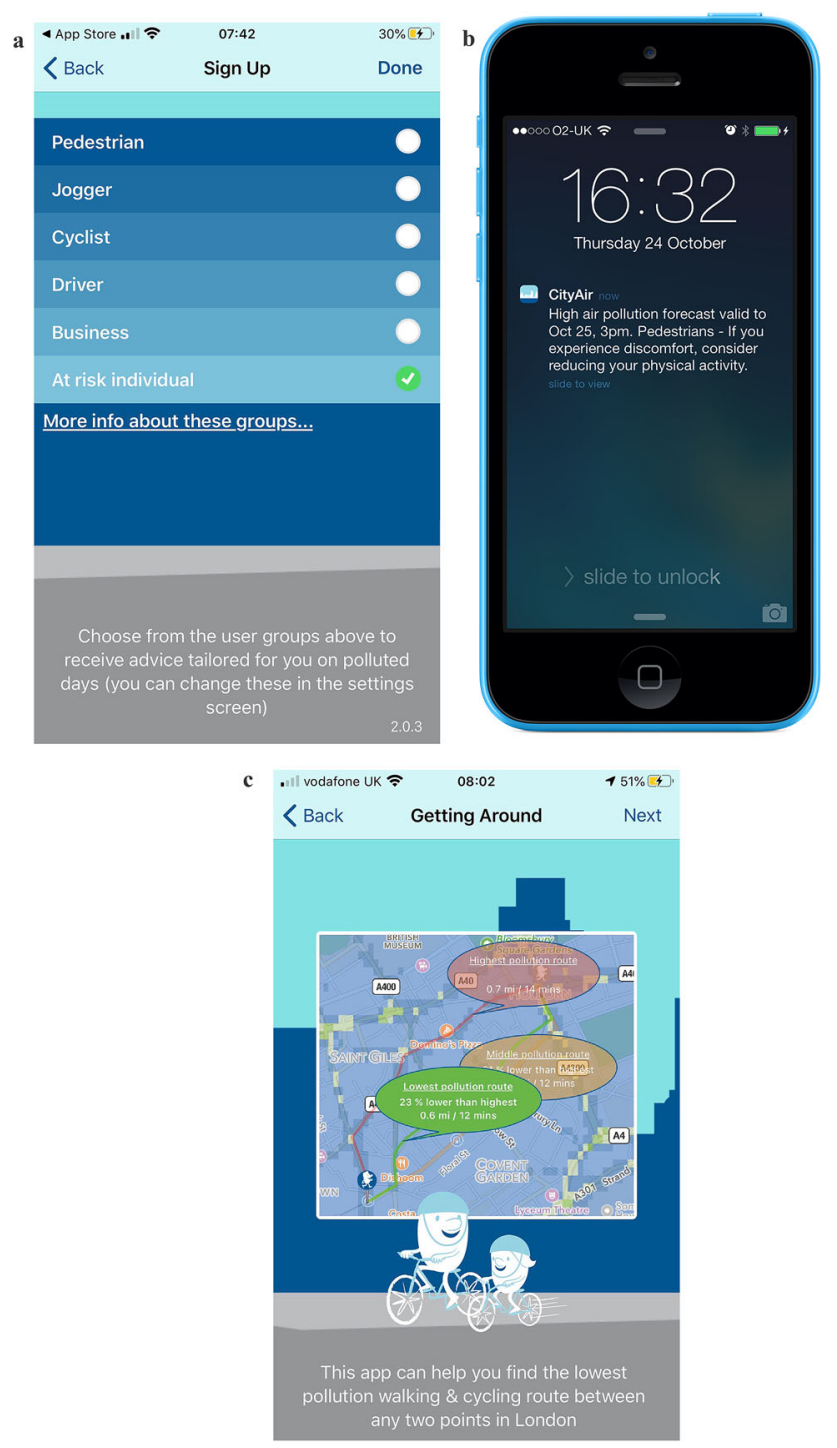

Fig. 3 CityAir smartphone app. The app shows: (1) advice tailored to specific user groups; (2) air pollution forecast; (3) low-pollution journey planners

Several actions in combination must however be taken since multiple measures, each producing a benefit of varying size, are likely to act cumulatively to produce significant change.

The response to the coronavirus disease 2019 (COVID-19) pandemic across the world, in the form of economic rescue packages, has however clearly demonstrated the power of governments and the speed at which they can act when the political will is there and when there is a shared sense of an emergency. We really need to hold onto this, and must guard against voices that may say we need to de-regulate to get the economy going again in a non-sustainable way. In support, findings suggest that the pandemic and, specifically, imposed lockdown measures could result in behavioural changes and thus environmental improvements to benefit those living with asthma. It has clearly given people the opportunity to appreciate how much they depend on exercise in treasured green spaces. There are also glimmers of hope that reduced reliance on the car and increased active travel may emerge. In the UK, an AA-Populus poll 
survey reported that one-fifth of drivers will use their cars less when restrictions are lifted [73]. Fear of contracting coronavirus on public transport has also led to a boom in cycle-towork schemes, whilst demand for greater mobility and exercise amid lifestyle changes has also boosted bike sales across the UK [74]. Mindset shifts such as these should now be skilfully harnessed with realistic policies and effective measures. In turn, they must be taken forth with political courage and investment so that air pollution no longer contributes to the development or worsening of respiratory ill health.

\section{ACKNOWLEDGEMENTS}

Funding. This study was funded by the National Institute for Health Research (NIHR) Health Protection Research Unit in Environmental Exposures and Health, a partnership between Public Health England and Imperial College. The views expressed are those of the author(s) and not necessarily those of the NIHR, Public Health England or the Department of Health and Social Care. The study was also part supported by the MRC Centre for Environment and Health, which is currently funded by the Medical Research Council (MR/S0196669/1, 2019-2024). Infrastructure support was provided by the NIHR Imperial Biomedical Research Centre (BRC). No Rapid Service Fee was received by the journal for the publication of this article.

Authorship. All named authors meet the International Committee of Medical Journal Editors (ICMJE) criteria for authorship for this article, take responsibility for the integrity of the work as a whole, and have given their approval for this version to be published.

Disclosures. Frank Kelly, Ian Mudway and Julia Fussell have nothing to disclose.

Compliance with Ethics Guidelines. This article is based on previously conducted studies and does not contain any new studies with human participants or animals performed by any of the authors.

Data Availability. Data sharing is not applicable to this article, as no datasets were generated or analysed during the current study.

Open Access. This article is licensed under a Creative Commons Attribution-Non-Commercial 4.0 International License, which permits any non-commercial use, sharing, adaptation, distribution and reproduction in any medium or format, as long as you give appropriate credit to the original author(s) and the source, provide a link to the Creative Commons licence, and indicate if changes were made. The images or other third party material in this article are included in the article's Creative Commons licence, unless indicated otherwise in a credit line to the material. If material is not included in the article's Creative Commons licence and your intended use is not permitted by statutory regulation or exceeds the permitted use, you will need to obtain permission directly from the copyright holder. To view a copy of this licence, visit http://creativecommons.org/licenses/bync/4.0/.

\section{REFERENCES}

1. World Health Organisation (WHO). Chronic respiratory diseases: Asthma. Q\&A Detail. Asthma. 2020. https://www.who.int/news-room/q-a-detail/asthma. Accessed 5 May 2020.

2. Dharmage SC, Perret JL, Custovic A. Epidemiology of asthma in children and adults. Front Pediatr. 2019;7:246

3. Asher MI, Montefort S, Bjorksten B, et al. Worldwide time trends in the prevalence of symptoms of asthma, allergic rhinoconjunctivitis, and eczema in childhood: ISAAC Phases One and Three repeat multicountry cross-sectional surveys. Lancet. 2006;368(9537):733-43.

4. To T, Stanojevic S, Moores G, et al. Global asthma prevalence in adults: findings from the cross-sectional world health survey. BMC Public Health. 2012;12:204. 
5. Royal College of Physicians/Royal College of Paediatrics and Child Health (RCP/RCPCH). Every breath we take: the lifelong impact of air pollution. Report of a working party. 2016. https://www. rcplondon.ac.uk/projects/outputs/every-breath-wetake-lifelong-impact-air-pollution. Accessed 5 May 2020.

6. Royal College of Paediatrics and Child Health/ Royal College of Physicians (RCPCH/RCP). The inside story: Health effects of indoor air quality on children and young people. 2020. https://www. rcpch.ac.uk/resources/inside-story-health-effectsindoor-air-quality-children-young-people. Accessed 6 May 2020.

7. Achakulwisut P, Brauer M, Hystad P, Anenberg SC. Global, national, and urban burdens of paediatric asthma incidence attributable to ambient $\mathrm{NO} 2$ pollution: estimates from global datasets. Lancet Planet Health. 2019;3(4):e166-78.

8. O'Byrne PM, Naya IP, Kallen A, Postma DS, Barnes PJ. Increasing doses of inhaled corticosteroids compared to adding long-acting inhaled b2- agonists in achieving asthma control. Chest. 2008;134: 1192-9.

9. Lalloo UG, Malolepszy J, Kozma D, et al. Budesonide and formoterol in a single inhaler improves asthma control compared with increasing the dose of corticosteroid in adults with mild-tomoderate asthma. Chest. 2003;123:1480-7.

10. Legorreta AP, Christian-Herman J, O'Connor RD, Hassan MM, Evans R, Leung KM. Compliance with national asthma management guidelines and specialty care: a health maintenance organization experience. Arch Intern Med. 1998;158:457-64.

11. Gaga M, Papageorgiou N, Zervas E, Gioulekas D, Konstantopoulos S. Control of asthma under specialist care: is it achieved? Chest. 2005;128:78-84.

12. Garcia E, Berhane KT, Islam T, et al. Association of changes in air quality with incident asthma in children in California, 1993-2014. JAMA. 2019;321: 1906-15.

13. Downs SH, Schindler C, Liu LJ, SAPALDIA Team, et al. Reduced exposure to PM10 and attenuated age-related decline in lung function. N Engl J Med. 2007;357:2338-47.

14. Schindler C, Keidel D, Gerbase MW, SAPALDIA Team, et al. Improvements in PM10 exposure and reduced rates of respiratory symptoms in a cohort of Swiss adults (SAPALDIA). Am J Respir Crit Care Med. 2009;179:579-87.

15. Hasunuma $H$, Ishimaru $Y$, Yoda $Y$, Shima $M$. Decline of ambient air pollution levels due to measures to control automobile emissions and effects on the prevalence of respiratory and allergic disorders among children in Japan. Environ Res. 2014;131:111-8.

16. Pope CA. Respiratory disease associated with community air pollution and a steel mill, Utah Valley. Am J Public Health. 1989;79:623-8.

17. Friedman MS, Powell KE, Hutwagner L, Graham LM, Teague WG. Impact of changes in transportation and commuting behaviors during the 1996 Summer Olympic Games in Atlanta on air quality and childhood asthma. JAMA. 2001;285:897-905.

18. Li Y, Wang W, Kan H, Xu X, Chen B. Air quality and outpatient visits for asthma in adults during the 2008 Summer Olympic Games in Beijing. Sci Total Environ. 2010;408(5):1226-7.

19. Mu L, Deng F, Tian L, et al. Peak expiratory flow, breath rate and blood pressure in adults with changes in particulate matter air pollution during the Beijing Olympics: a panel study. Environ Res. 2014;133:4-11.

20. Howden-Chapman P, Pierse N, Nicholls S, et al. Effects of improved home heating on asthma in community dwelling children: randomised controlled trial. BMJ. 2008;337:a1411.

21. Pilotto LS, Nitschke M, Smith BJ, et al. Randomized controlled trial of unflued gas heater replacement on respiratory health of asthmatic schoolchildren. J Epidemiol. 2004;33:208-14.

22. Cames M, Helmers E. Critical evaluation of the European diesel carboom-global comparison, environmental effects and various national strategies. Environ Sci Eur. 2015;25:15.

23. European Automobile Manufacturers Association. 2019. https://www.acea.be/publications/article/ report-vehicles-in-use-europe-2019. Accessed 13 May 2020.

24. European Commission (EC). Non-Road mobile machinery emissions 2020. https://ec.europa.eu/ growth/sectors/automotive/environment-protection/ non-road-mobile-machinery_en. Accessed 13 May 2020.

25. den Boer E,Faber J, Nelissen D. Study of emission control and energy efficiency measures for ships in the port area. International Maritime Organisation (IMO). 2015. https://www.cedelft.eu/en/ publications/1636/study-of-emission-control-andenergy-efficiency-measures-for-ships-in-the-portarea. Accessed 13 May 2020.

26. Ryan PH, Reponen T, Simmons M, et al. The impact of an antiidling campaign on outdoor air quality at 
four urban schools. Environ Sci Process Impacts. 2013;15:2030-7.

27. Mayor of London. Latest data shows two million Londoners living with illegal toxic air. 2019. https:// www.london.gov.uk/press-releases/mayoral/twomillion-londoners-live-with-illegal-toxic-air. Accessed 11 May 2020.

28. Di Q, Wang Y, Zanobetti A, et al. Air pollution and mortality in the medicare population. N Engl J Med. 2017;376:2513-22.

29. Fecht D, Fischer P, Fortunato L, et al. Associations between air pollution and socioeconomic characteristics, ethnicity and age profile of neighbourhoods in England and the Netherlands. Environ Pollut. 2015;198:201-10.

30. Sheridan CE, Roscoe CJ, Gulliver J, de Preux L, Fecht D. Inequalities in exposure to nitrogen dioxide in parks and playgrounds in greater London. Int J Environ Res Public Health. 2019;16(17):3194.

31. Kelly FJ, Fussell JC. Improving indoor air quality, health and performance within environments where people live, travel, learn and work. Atmos Environ. 2019;200:90-109.

32. United Nations (UN). World urbanization prospects. The 2018 revision. New York: United Nations; 2018.

33. Carslaw DC. Defra urban model evaluation analysis-phase 1. Department for Environment, Food \& Rural Affairs/UK Air Information Resource. 2011. https://uk-air.defra.gov.uk/library/reports?report_ id=654. Accessed 13 May 2020.

34. Anenberg SC, Miller J, Minjares R. Impacts and mitigation of excess diesel-related NOx emissions in 11 major vehicle markets. Nature. 2017;545: 467-71.

35. Mudway IS, Dundas I, Wood HE, et al. Impact of London's low emission zone on air quality and children's respiratory health: a sequential annual cross-sectional study. Lancet Public Health. 2019;4(1):e28-40.

36. Air Quality Expert Group (AQEG). Non-exhaust emissions from road traffic. 2019. https://uk-air. defra.gov.uk/library/reports.php?report_id=992. Accessed 5 May 2020.

37. Selley L, Schuster L, Marbach H, et al. Brake dust exposure exacerbates inflammation and transiently compromises phagocytosis in macrophages. Metallomics. 2020;12(3):371-86.

38. Behrentz E, Sabin LD, Winer AM, et al. Relative importance of school bus-related microenvironments to children's pollutant exposure. J Air Waste Manag Assoc. 2005;55:1418-30.

39. Lee ES, Fung CC, Zhu Y. Evaluation of a high efficiency cabin air (HECA) filtration system for reducing particulate pollutants inside school buses. Environ Sci Technol. 2015;49(6):3358-65.

40. Adar SD, D'Souza J, Mendelsohn-Victor K, et al. Markers of inflammation and coagulation after long-term exposure to coarse particulate matter: a cross-sectional analysis from the multi-ethnic study of atherosclerosis. Environ Health Perspect. 2015;123(6):541-8.

41. Vardoulakis S, Kettle R, Cosford P, et al. Local action on outdoor air pollution to improve public health. Int J Public Health. 2018;63(5):557-65.

42. European Court of Auditors (ECA). Sustainable urban mobility in the EU: no substantial improvement is possible without Member States' commitment. 2020. https://www.eca.europa.eu/en/Pages/ DocItem.aspx?did=53246. Accessed 13 May 2020.

43. Chng S, Abraham C, White MP, Skippon S. To drive or not to drive? A qualitative comparison of car ownership and transport experiences in London and Singapore. Transport Res Interdiscipl Perspect. 2019;2:100030.

44. Vardoulakis S, Fisher BEA, Pericleous K, GonzalezFlesca N. Modelling air quality in street canyons: a review. Atmos Environ. 2003;37:155-82.

45. Salmond JA, Tadaki M, Vardoulakis S, et al. Health and climate related ecosystem services provided by street trees in the urban environment. Environ Health. 2016;15:95-111.

46. Cariñanos P, Grilo F, Pinho P, et al. Estimation of the allergenic potential of urban trees and urban parks: towards the healthy design of urban green spaces of the future. Int J Environ Res Public Health. 2019;16(8):1357.

47. Russell-Jones R. Air pollution in the UK: better ways to solve the problem. BMJ. 2017;358:j2713.

48. Andersen LB. Active commuting is beneficial for health. BMJ. 2017;358:j1740.

49. Hart JF, Ward TJ, Spear TM, Rossi RJ, Holland NN, Loushin BG. Evaluating the effectiveness of a commercial portable air purifier in homes with wood burning stoves: a preliminary study. J Environ Public Health. 2011;2011:324809.

50. Triana CA, Sarmiento OL, Bravo-Balado A, et al. Active streets for children: the case of the Bogota Ciclovia. PLoS ONE. 2019;14(5):e0207791. 
51. Montero S. Worlding Bogotá's Ciclovía. Latin Am Perspect. 2016;44(2):111-31.

52. Lang JE. The impact of exercise on asthma. Curr Opin Allergy Clin Immunol. 2019;19(2):118-25.

53. Weschler CJ. Changes in indoor pollutants since the 1950s. Atmos Environ. 2009;43(1):153-69.

54. Morrell P. Low carbon construction, final report. London: HM Government, Innovation \& Growth Team. 2010. https://assets.publishing.service.gov.uk/ government/uploads/system/uploads/attachment_ data/file/31773/10-1266-low-carbon-constructionIGT-final-report.pdf. Accessed 31 May 2020.

55. Yu CWF, Kim JT. Low-carbon housings and indoor air quality. Indoor Built Environ. 2012;21(1):5-15.

56. Belanger K, Holford TR, Gent JF, Hill ME, Kezik JM, Leaderer BP. Household levels of nitrogen dioxide and pediatric asthma severity. Epidemiology. 2013;24:320-30.

57. Svanes $\varnothing$, Bertelsen RJ, Lygre SHL, et al. Cleaning at home and at work in relation to lung function decline and airway. Am J Respir Crit Care Med. 2018;197:1157-63.

58. Annesi-Maesano I, Hulinm M, Lavaud F, et al. Poor air quality in classrooms related to asthma and rhinitis in primary schoolchildren of the French 6 cities study. Thorax. 2012;67:682-8.

59. Callesen M, Beko G, Weschler CJ, et al. Associations between selected allergens, phthalates, nicotine, polycyclic aromatic hydrocarbons, and bedroom ventilation and clinically confirmed asthma, rhinoconjunctivitis, and atopic dermatitis in preschool children. Indoor Air. 2014;24:136-47.

60. Bertelsen RJ, Carlsen KC, Carlsen KH, et al. Childhood asthma and early life exposure to indoor allergens, endotoxin and beta (1,3)-glucans. Clin Exp Allergy. 2009;40:307-16.

61. Hsu J, Qin X, Beavers SF, Mirabelli MC. Asthma related school absenteeism, morbidity and modifiable factors. Am J Prevent Med. 2016;51:23-32.

62. Mi YH, Norback D, Tao J, Mi YL, Ferm M. Current asthma and respiratory symptoms among pupils in Shanghai, China: influence of building ventilation, nitrogen dioxide, ozone, and formaldehyde in classrooms. Indoor Air. 2006;16:454-6.
63. Liu NM, Grigg J. Diesel, children and respiratory disease. BMJ Paediatr Open. 2018;2(1):e000210.

64. Emden J, Murphy L. Lethal but legal: air pollution from domestic burning. London: Institute of Public Policy Research. 2018. https://www.ippr.org/ research/publications/lethal-but-legal. Accessed 5 May 2020.

65. Breathe London. Wearables Study: Engaging primary school children to monitor air pollution in London. 2019. https://www.breathelondon.org/ wearables/. Accessed 6 May 2020.

66. Chan Y-FY, Bot BM, Zweig M, et al. The asthma mobile health study, smartphone data collected using ResearchKit. Sci Data. 2018;5:180096.

67. Jones PJ, Koolhof IS, Wheeler AJ, et al. Can smartphone data identify the local environmental drivers of respiratory disease? Environ Res. 2020;182: 109118.

68. Hadley MB, Baumgartner J, Vedanthan R. Developing a clinical approach to air pollution and cardiovascular health. Circulation. 2018;137(7): 725-42.

69. Faber T, Been JV, Reiss IK, Mackenbach JP, Sheikh A. Smoke-free legislation and child health. NPJ Prim Care Respir Med. 2016;26:16067.

70. Kelly FJ, Fuller GW, Walton HA, Fussell JC. Monitoring air pollution: use of early warning systems for public health. Respirology. 2012;17(1):7-19.

71. London Air Quality Network (LAQN). London air. Mobile apps. 2020. https://www.londonair.org.uk/ LondonAir/MobileApps/. Accessed 11 May 2020.

72. City of London. CityAir App. 2019. https:// cityairapp.com. Accessed 11 May 2020.

73. Automobile Association (AA). Life After Lockdown. 2020. https://www.theaa.com/about-us/newsroom/ motoring-news/life-after-lockdown. Accessed 7 May 2020.

74. British Broadcasting Corporation (BBC). Coronavirus: Boom time for bikes as virus changes lifestyles. 2020. https://www.bbc.co.uk/news/business52564351. Accessed 7 May 2020. 